\title{
DUALISME YURISDIKSI ANTARA PERADILAN UMUM DAN PERADILAN AGAMA TERHADAP SENGKETA EKONOMI SYARIAH
}

\author{
Jesi Aryanto \\ Fakultas Hukum Universitas YARSI \\ Email : arya_mesuji@yahoo.co.id \\ aryamesuji@gmail.com
}

\begin{abstract}
Any measures to settle issues or disputes related to Syariah economy-according to UU No.3 2006 article 49 on Religious Court-are parts of religious court office's authority. Another law on Syariah Banking-UU No.21 2008 article 55similarly stipulates the matter. The latter-particularly clauses 1 and 2somehow consists of contradictio in terminis, i.e. in subsection 2 point ' $d$ ' where the phrase "Court in General Justice" refers to non-litigation settlement, whichtherefore-contradicts its norm. Thus, such a stipulation should be overridden since it is clear that General Justice refers to litigation settlement. Based on principles of Islamic personality and compliance with Islamic laws, as stated in UU No.3 2006 on Religious Court, settlements of disputes particularly the ones related to Syariah Banking should be the authority of religious court office. Moreover, this goes hand in hand with lex-specialis-derogate-legi-generalis principle, overriding general rules when specific ones prevail. In this case, the law (UU No.3 2006 on Religious Court) serves as the specific one which should override UU No.21 2008 article 55 subsection 2 point ' $d$ ' which functions as the general law. Although the Civil Code article 1338 guarantees the rights for making legal contracts, one cannot earn absolute freedom to formulate or design the contents in the contracts since they must abide by Syariah laws. The main principle of settling Syariah-related disputes-as stipulated in Provisions of article 1 paragraph 7 jo. UU No.21 2008 article 2 on Syariah Banking-must not contradict the Syariah principles. A sanction-both in the form of fining for customers who can actually afford but deliberately procrastinate settling debt payments and in the form of penalty or performance bond (dwangsom) paid for default or excuse of performance (wanprestasi) due to customers' lack of careful payments - can actually be imposed, providing that the referred items have been specifically mentioned in the contract, signed by both parties in a bid to uphold the maqasyd syariah (the fundamentals of Syariah) to discipline customers. This is in line with such Islamic references as Al-Baqarah 280, al-Hadits, as well as fatwa DSN No.17/DSN-MUI/IX/2000 on Sanctions Imposed on Customers who Procrastinate Settling Payments.
\end{abstract}

Keywords: Syariah principles, Rights for Making Legal Contracts, Maqasyd Syariah 


\begin{abstract}
Abstrak
Penyelesaian sengketa ekonomi syariah merupakan kewenangan Peradilan Agama berdasarkan ketentuan Pasal 49 UU No.3 Tahun 2006 tentang Peradilan Agama, yang diperkuat dengan ketentuan Pasal 55 UU No.21 Tahun 2008 tetang Perbankan Syariah. Ketetuan Pasal 55 ayat (1) dan ayat (2) telah terjadi contradictio in terminis. Pada penjelasan ayat (2) huruf d frasa "Pengadilan dalam lingkungan Peradilan Umum" telah diposisikan sebagai penyelesaian non litigasi merupakan penempatan norma yang keliru. Oleh karenanya, ketentuan tersebut haruslah dikesampingkan dikarenakan Peradilan Umum merupakan penyelesaian litigasi. Berdasarkan asas personalitas keislaman dan asas penundukan diri secara sukarela kepada hukum Islam, sebagaimana ketentuan UU No.3 Tahun 2006 tentang Peradilan Agama, maka penyelesaian sengketa ekonomi syariah khususnya bank syariah menjadi kewenangan peradilan agama. Selain itu, asas lex specialis derogate legi generalis, yaitu aturan khusus mengenyampingkan aturan yang umum. Dalam hal ini, ketentuan UU No.3 Tahun 2006 tentang Peradilan Agama adalah sebagai aturan khusus yang mengenyampingkan ketentuan Pasal 55 ayat (2) dan penjelasannya pada hurufd UU No.21 Tahun 2008 tentang Perbankan Syariah yang merupakan aturan umum. Asas kebebasan berkontrak sebagaimana ketentuan Pasal 1338 KUHPerdata tidaklah bersifat absolut sepanjang bertentangan dengan syariah, dan sepanjang tidak bertentangan dengan syariah maka perikatan/perjanjian tersebut boleh dilaksanakan.

Prinsip utama penyelesaian sengketa syariah adalah tidak boleh bertentangan dengan prinsip-prinsip syariah sebagaimana ketentuan Pasal 1 ayat (7) jo. Pasal 2 UU No.21 Tahun 2008 tentang Perbankan Syariah. Pada dasarnya penerapan sanksi baik berupa denda terhadap setiap keterlambatan pembayaran utang oleh nasabah mampu yang sengaja melalaikan dan menunda-nunda kewajibannya untuk melaksanakan pembayaran, maupun sanksi dwangsom (uang paksa) terhadap perbuatan wanprestasi yang dilakukan dengan unsur kesengajaan dan kelalaian, maka sanksi tersebut dapat dijatuhkan sepanjang telah disepakati dalam akad yang telah ditandatangani bersama oleh para pihak, yang bertujuan untuk menegakkan maqasyd syariah agar nasabah lebih disiplin dalam melaksanakan kewajibannya. Hal ini sejalan dengan al-Quran (QS. Al-Baqarah: 280) dan al-Hadits serta fatwa DSN No.17/DSN-MUI/IX/2000 tentang Sanksi Atas Nasabah Mampu yang Menunda-nunda Pembayaran.
\end{abstract}

Keywords: Prinsip Syariah, Kebebasan Berkontrak, Maqasyd Syariah. 


\section{PENDAHULUAN}

Perkembangan suatu negara dapat dilihat dari pertumbuhan ekonominya, khususnya dibidang perbankan. Perbankan adalah salah satu agen pembangunan (agent of development). Karena fungsi utama dari perbankan itu sebagai lembaga yang menghimpun dana dari masyarakat dalam bentuk simpanan dan menyalurkan kembali kepada masyarakat dalam bentuk kredit atau pembiayaan. Oleh karena itulah fungsi ini dikenal sebagai intermediasi keuangan (financial intermediary function). Kemudian dana yang terkumpul di bank akan dijadikan sebagai sumber dana dari keberlangsungan pembangunan. Mengingat fungsi perbankan yang sangat penting, maka tidak heran jika lembaga keuangan seperti bank, merupakan lembaga yang sarat akan pengaturan baik ditingkat undangundang maupun pada peraturan teknis pelaksanaan yang tertuang dalam berbagai Peraturan Bank Indonesia (PBI).

Sebagai lembaga intermediary dan seiring dengan situasi lingkungan eksternal dan internal perbankan yang mengalami perkembangan pesat, bank syariah akan selalu berhadapan dengan berbagai jenis risiko dengan tingkat kompleksitas yang beragam dan melekat pada kegiatan usahanya. Risiko dalam konteks perbankan merupakan suatu kejadian potensial, baik yang dapat diperkirakan (anticipated) maupun yang tidak dapat diperkirakan (unanticipated) yang berdampak negatif terhadap pendapatan dan permodalan bank yang tentunya menimbulkan persoalan hukum dan harus diselesaikan dengan piranti hukum.

Peranan lembaga perbankan sebagai salah satu pilar ekonomi yang utama, dituntut untuk mampu mewujudkan tujuan perbankan nasional sebagai agent of development dalam upaya mencapai tujuan nasional sebagaimana telah didukung oleh peraturan dan perundang - undangan, serta sistem perbankan yang relatif sehat dan stabil. ${ }^{1}$ Seperti yang terkandung dalam UU No.7 Tahun 1992 sebagaimana telah diubah dengan UU No.10 Tahun 1998 tentang Perbankan, yang menganut dual banking system (konvensional dan syariah). Terhadap sistem dual banking system muncul beberapa kekhawatiran ditengah masyarakat seperti

\footnotetext{
${ }^{1}$ Hermansyah, Hukum Perbankan Nasional Indonesia, (Jakarta, Kencana Media Group, 2005), Cet. ke-4, hlm. 41
} 
terjadi percampuran dana atau aset antara yang berasal dari bunga dengan yang diperoleh berdasarkan prinsip syariah. Sehingga lahirlah UU No.21 Tahun 2008 tentang Perbankan Syariah, yang secara khusus membahas persoalan perbankan syariah yang tidak membatalkan UU No.7 Tahun 1992 jo UU No.10 Tahun 1998 sepanjang tidak bertentangan dengan undang-undang Perbankan Syariah tersebut.

Secara umum pengertian Bank Islam (Islamic Bank) adalah bank yang pengoperasiannya disesuaikan dengan prinsip syariat Islam. Banyak istilah yang diberikan untuk menyebut entitas Bank Islam selain istilah Bank Islam itu sendiri, yakni Bank Tanpa Bunga (Interest-Free Bank), Bank Tanpa Riba (Lariba Bank), dan Bank Syariah (Shari'a Bank). Di Indonesia secara teknis yuridis penyebutan Bank Islam mempergunakan istilah resmi "Bank Syariah", atau yang secara lengkap disebut "Bank Berdasarkan Prinsip Syariah". 2

Kegiatan operasional bank syariah berdasarkan prinsip syariah yang aturan perjanjiannya berdasarkan hukum Islam antara bank dan pihak lain untuk penyimpanan dan atau pembiayaan kegiatan usaha, atau kegiatan lainnya yang dinyatakan sesuai dengan syariah, antara lain pembiayaan berdasarkan prinsip bagi hasil (mudharabah), pembiayaan berdasarkan prinsip penyertaan modal (musharakah), prinsip jual beli dengan memperoleh keuntungan (murabahah) atau pembiayaan barang modal berdasarkan prinsip sewa murni tanpa pilihan (ijarah), atau dengan adanya pilihan pemindahan kepemilikian atas barang yang disewa dari pihak bank oleh pihak lain (ijarah wa iqtina).

Fungsi bank syariah sebagai lembaga intermediasi (intermediary institution) yang mengerahkan dana dari masyarakat dan menyalurkan kembali kepada masyarakat yang membutuhkannya dalam bentuk fasilitas pembiayaan dengan jenis keuntungan yang berasal dari transaksi-transaksi yang dilakukan disebut dengan imbalan, baik berupa jasa (fee-base income) maupun mark-up atau profit margin, serta bagi hasil (loss and profit sharing). ${ }^{3}$ Disamping itu, bank syariah juga membebaskan transaksi dari mekanisme bunga (interest free), melakukan

\footnotetext{
${ }^{2}$ http://omperi.wikidot.com/Sejarah Perkembangan Hukum Perbankan Syariah Di Indonesia.
} 
kegiatan-kegiatan usaha yang bersifat multi-finance dan perdagangan (trading). ${ }^{4}$ Hal ini berkaitan dengan sifat dasar transaksi bank syariah yang merupakan investasi dan jual beli serta sangat beragamnya pelaksanaan pembiayaan yang dapat dilakukan oleh bank syariah, seperti pembiayaan dengan prinsip murabahah (jual beli), ijarah (sewa), atau ijarah wa iqtina (sewa beli), dan lain-lain.

Dalam praktiknya, kegiatan ekonomi syariah khususnya dibidang perbankan syariah tidak jarang terjadi sengketa seperti pada pembiayaan bermasalah atau non performing finance merupakan risiko yang terkandung dalam setiap pemberian pembiayaan oleh bank. Risiko tersebut berupa keadaan dimana pembiayaan tidak dapat kembali tepat waktu, sehingga diperlukan penyelesaiannya. Terkait dengan penyelesaian pembiayaan bermasalah, selain penyelesaian secara langsung oleh para pihak melalui musyawarah mufakat, tentu tidak lepas dari lembaga peradilan yang berwenang untuk memeriksa dan memutus sengketa syariah, sebagaimana ketentuan Pasal 55 ayat (2) UU No.21 Tahun 2008 tentang Perbankan Syariah yang mengandung contradictio in terminis (berlawanan arti) dan seolah-olah menganulir kompetensi absolut Peradilan Agama Pasal 49 UU No.3 Tahun 2006 tentang Peradilan Agama. Di satu sisi, seluruh sengketa ekonomi syariah diselesaikan di Pengadilan Agama, tapi di sisi lain membuka kesempatan kepada Peradilan Umum untuk menyelesaikannya, padahal keduanya memiliki kompetensi absolut yang berbeda.

Dari fenomena tersebut terdapat tarik ulur antara kompetensi Peradilan Agama dengan kompetensi Peradilan Umum dalam menyelesaikan sengketa syariah, Peradilan manakah yang berwenang?, bagaimana penerapan sanksi denda dan uang paksa (dwangsom) dalam penyelesaian sengketa syariah ?. Mengingat dalam hal ini sangat diperlukan kepastian hukum terhadap penyelesaian sengketa syariah khususnya dibidang perbankan syariah tersebut.

\section{METODE PENELITIAN}

Metodologi penelitian yang dipergunakan dalam penelitian ini adalah penelitian yuridis normatif, yaitu suatu penelitian yang mengacu kepada norma- 
norma hukum yang terdapat dalam peraturan perundang-undangan. Penelitian ini merupakan penelitian dengan kajian studi pustaka (library research) dengan mengumpulkan beberapa sumber pustaka yang berkaitan dengan pembahasan dalam penelitian tersebut. Untuk menguraikan dan menjelaskan pengertian tentang masalah hukum yang data-datanya telah dikumpulkan dapat dilakukan analisis.

Dalam hal metode analisis penulis menggunakan metode deskriptif analitis. Semua data-data yang diperoleh dari library research dikumpulkan dan digabungkan untuk kemudian dianalisa, dan hasil analisa tersebut ditarik suatu kesimpulan sebagai hasil akhir yang merupakan jawaban dari rumusan masalah sebagaimana yang menjadi tujuan dari penelitian tersebut, sehingga dapat diketahui apakah Peradilan Agama atau Peradilan Umum yang berwenang mengadili serta bagaimana praktik penerapan sanksi denda dan uang paksa (dwangsom) terhadap sengketa syariah khususnya di bidang perbankan syariah.

\section{PEMBAHASAN}

\section{Antara Yurisdiksi Peradilan Agama dan Peradilan Umum?}

Kegiatan usaha syariah khususnya di bidang perbankan syariah dilaksanakan atas kemitraan dan kebersamaan dalam untung dan rugi (profit and lost sharing) serta amanah sedemikian rupa. Namun, bukan berarti aman dari segala masalah, tidak menutup kemungkinan terjadinya sengketa dan perselisihan berupa pengingkaran atau pemecahan perjanjian (breach of contract), cidera janji (wan prestasi) perbuatan melawan hukum (onrechtmatigedaad) dan lain sebagainya.

Dalam kajian hukum dikenal dengan dua macam mekanisme penyelesaian sengketa yang disebut jalur litigasi dan non litigasi. Penyelesaian sengketa melalui jalur non litigasi adalah mekanisme penyelesaian sengketa di luar pengadilan, yang pada umumnya menggunakan mekanisme yang hidup ditengah masyarakat yang bentuk dan macamnya sangat bervariasi seperti kekeluargaan, perdamaian, musyawarah, dan lain sebagainya. Setelah upaya non litigasi tidak menghasilkan penyelesaian dan solusi (Pasal 16 ayat (2) UU No.4 Tahun 2004), maka jalan 
terakhir penyelesaiannya dilakukan melalui jalur litigasi yang merupakan the last resort atau ultimatum remedium (upaya terakhir) sebagai mekanisme penyelesaian melalui lembaga peradilan sesuai dengan peraturan perundang-undangan. ${ }^{5}$ Meskipun kewenangan suatu lingkungan peradilan telah ditentukan oleh peraturan perundang-undangan, namun pada kenyataannya tidak jarang masih menimbulkan permasalahan kewenangan mengadili yang disebut yurisdiksi atau kompetensi, yaitu kewenangan suatu lembaga peradilan dalam mengadili perkara tertentu sesuai dengan ketentuan yang digariskan oleh peraturan perundang - undangan. ${ }^{6}$

Mengenai badan peradilan mana yang berwenang menyelesaikan sengketa perbankan syariah memang sempat menjadi perdebatan di berbagai kalangan terkait UU No.3 Tahun 2006 tentang Peradilan Agama dan UU No.21 Tahun 2008 tentang Perbankan Syariah, apakah menjadi kewenangan Peradilan Agama atau Peradilan Umum. Kontroversi seputar kompetensi Peradilan Agama dalam perkara ekonomi syariah adalah terkait dengan beberapa persoalan yang diantaranya adalah ${ }^{7}$ :

1) Hukum Islam yang hidup dan berlaku di Indonesia bukan hukum positif, oleh karena itu tidak dapat dipaksakan pemberlakuannya;

2) Peraturan perundang-undangan dan regulasi yang ada disamping tidak sinkron, juga antara satu dan lainnya saling bertentangan;

3) Peradilan Agama belum mempunyai sejumlah instrumen hukum materil dan formil dalam menangani perkara ekonomi syariah, sehingga akan berdampak pada ketidakpastian hukum dan disparitas putusan antara satu hakim dengan lainnya;

4) Secara kelembagaan, performa dan sumber daya manusia Peradilan Agama tidak mumpuni dalam menangani perkara ekonomi syariah, karena selain tidak didukung oleh sarana dan prasarana yang tidak memadai, juga tidak familiar menangani perkara bisnis dan komersial.

\footnotetext{
${ }^{5}$ Bambang Sutiyoso, Penyelesaian Sengketa Bisnis, (Yogyakarta: Citra Media, 2006), hlm. 9

${ }^{6} \mathrm{H}$. Hasbi Hasan, Kompetensi Peradilan Agama Dalam Penyelesaian Perkara Ekonomi Syariah, (Jakarta: Gramata Publishing, 2010), hlm. 121

${ }^{7}$ Ibid., hlm. 183
} 
Terlepas dari kontroversi tersebut, melalui tinjauan beberapa perspektif terhadap Undang - Undang Peradian Agama (UU No.3 Tahun 2006) dan UndangUndang Perbankan Syariah (UU No.21 Tahun 2008) sebagai landasan hukum yang akan dibahas dalam pembahasan ini, yang setidaknya dapat menjawab kontroversi mengenai kompetensi Peradilan Agama dalam menyelesaikan perkara ekonomi syariah.

Secara prinsip, penegakan hukum di Indonesia hanya dapat dilakukan oleh kekuasaan kehakiman (judicial power) yang dilembagakan secara konstitusional yang lazim disebut badan yudikatif (Pasal 24 UUD 1945). Pasal 2 UU No.14 Tahun 1970 sebagaimana telah diubah dengan UU No.35 Tahun 1999 yang diubah menjadi UU No.4 Tahun 2004 dan terakhir diubah dengan UU No.48 Tahun 2009 tentang Kekuasaan Kehakiman, secara tegas menyatakan bahwa yang berwenang dan berfungsi melaksanakan peradilan hanya badan-badan peradilan yang dibentuk berdasarkan undang - undang. Di luar itu tidak dibenarkan karena tidak memenuhi syarat formal dan official dan bertentangan dengan prinsip under the authority of law.

Kemudian, dalam konstitusi negara Republik Indonesia, Pasal 24 ayat (2) UUD 1945 (amandemen ketiga tahun 2001) jo. Pasal 10 UU No.4 Tahun 2004 tentang Kekuasaan Kehakiman, dijelaskan badan peradilan yang berada di bawah kekuasaan Mahkamah Agung adalah lingkungan Peradilan Umum, lingkungan Peradilan Agama, lingkungan Peradilan Militer dan lingkungan Peradilan Tata Usaha Negara. Namun demikian, dalam penjelasan Pasal 3 ayat (1) jo Pasal 16 (2) UU No. 4 Tahun 2004 dinyatakan bahwa, tidak menutup kemungkinan penyelesaian perkara dilakukan di luar peradilan negara melalui perdamaian atau arbitrase.

Keempat lingkungan peradilan yang berada dibawah Mahkamah Agung merupakan penyelenggara kekuasaan negara di bidang yudikatif, secara konstitusional bertindak menyelenggarakan peradilan untuk menegakkan hukum dan keadilan (to enforce the truth and justice) dalam kedudukannya sebagai pengadilan negara (state court). Dengan demikian, Pasal 24 ayat (2) UUD 1945 dan Pasal 2 jo. Pasal 10 ayat (2) UU No.4 Tahun 2004 merupakan landasan sistem 
peradilan negara (state court system) di Indonesia, yang dipisahkan berdasarkan kompetensi atau yurisdiksi (separation court system based on jurisdiction). ${ }^{8}$

Sistem pemisahan kompetensi ini harus didasarkan pada beberapa hal, yaitu :

1. Didasarkan pada lingkungan kompetensi.

2. Masing-masing lingkungan memiliki kompetensi mengadili tertentu (diversity jurisdiction).

3. Kompetensi tertentu tersebut menciptakan terjadinya kompetensi absolut pada masing-masing lingkungan sesuai dengan subject matter of jurisdiction.

4. Masing-masing lingkungan hanya berkompeten mengadili sebatas kasus yang dilimpahkan oleh undang-undang.

Rasio penentuan batas kompetensi setiap lingkungan peradilan adalah agar terbina suatu pelaksanaan kekuasaan kehakiman yang tertib antar masing-masing lingkungan peradilan. Masing-masing lembaga peradilan harus berjalan pada rel yang telah ditetapkan, sehingga tidak terjadi perebutan kompetensi. Selain itu, penentuan batas kompetensi lembaga peradilan bertujuan untuk membina kekuasaan kehakiman yang tertib, sekaligus memberikan ketenteraman dan kepastian hukum bagi setiap anggota masyarakat pencari keadilan untuk mengajukan perkara.

Berbicara mengenai kompetensi lingkungan Peradilan Agama dalam kedudukannya sebagai salah satu pelaksana kekuasaan kehakiman (judicial power) di Indonesia, harus merujuk pada ketentuan UU No.3 Tahun 2006 tentang Perubahan Atas UU No.7 Tahun 1989 tentang Peradilan Agama. Kompetensi absolut Peradilan Agama diatur dalam Pasal 49 s/d 53 UU No.3 Tahun 2006. Dengan lahirnya UU No.3 Tahun 2006 tersebut telah membawa sejumlah perubahan mendasar bagi lingkungan Peradilan Agama, terutama menyangkut kewenangannya. Ruang lingkup kewenangan Peradilan Agama menjadi lebih luas dibandingkan sebelumnya berdasarkan UU No.7 Tahun 1989 yang hanya meliputi perkara-perkara di bidang perkawinan, kewarisan, wasiat, hibah, wakaf dan shadaqah. Dengan berlakunya UU No.3 Tahun 2006 kewenangan Peradilan

\footnotetext{
${ }^{8}$ M. Yahya Harahap, Hukum Acara Perdata, (Jakarta: Sinar Grafika, 2008), Cet. Ke-8, hlm. 180-181
} 
Agama selain perkara-perkara di bidang tersebut ditambah dengan perkaraperkara dalam bidang zakat, infak, dan ekonomi syariah. ${ }^{9}$

Dalam UU No.3 Tahun 2006 paling tidak terdapat 3 (tiga) hal penting yang merupakan terobosan baru dalam ruang lingkup kewenangan Peradilan Agama, yaitu:

1. Penghapusan pilihan hukum (hak opsi) dalam sengketa kewarisan;

2. Diberikan kewenangan untuk memutus sengketa hak milik; dan

3. Diberlakukannya asas penundukan diri terhadap hukum Islam yang merupakan salah satu dasar kewenangan Peradilan Agama.

Ketentuan Pasal 49 UU No.3 Tahun 2006 menyatakan bahwa "Pengadilan Agama bertugas dan berwenang memeriksa, memutus, dan menyelesaikan perkara di tingkat pertama antara orang-orang yang beragama Islam di bidang: $a$. perkawinan, b. waris, c. wasiat, d. hibah, e. wakaf, f. zakat, g. infaq, h. shadaqah, dan i. ekonomi syariah."

Khusus mengenai ekonomi syariah, penjelasan Pasal 49 huruf i, menyebutkan bahwa yang dimaksud dengan "ekonomi syariah" adalah perbuatan atau kegiatan usaha yang dilaksanakan menurut prinsip syariah. Prinsip dasar syariah yang membedakan ekonomi syariah dengan ekonomi konvensional adalah ridha (kebebasan berkontrak), ta'awun, bebas riba, bebas gharar, bebas tadlis, bebas maisir, obyek yang halal dan amanah. Bidang ekonomi syariah dimaksud meliputi: a. bank syariah; $b$. asuransi syariah; $c$, reasuransi syariah; $d$. reksadana syariah; e. obligasi syariah dan surat berharga berjangka menengah syariah; f. sekuritas syariah; g. pembiayaan syariah; $h$. pegadaian syariah; $i$. dana pensiun lembaga keuangan syariah; j. bisnis syariah; dan k. lembaga keuangan mikro syariah.

Dalam penjelasannya pasal tersebut dapat dipahami bahwa jangkauan kewenangan memeriksa, mengadili, memutus, dan menyelesaikan perkara di lingkungan peradilan agama dalam bidang ekonomi syariah telah meliputi

\footnotetext{
${ }^{9}$ Dalam paragraf pertama penjelasan umum UU No.3 Tahun 2006 tentang Peradilan Agama, antaralain dinyatakan bahwa: “... penegasan kewenangan peradilan agama tersebut dimaksudkan untuk memberikan dasar hukum kepada pengadilan agama dalam menyelesaikan perkara tertentu tersebut, termasuk pelanggaran atas undang-undang tentang perkawinan dan peraturan pelaksananya...”.
} 
keseluruhan bidang ekonomi syariah yang disebut sebagai perbuatan atau kegiatan usaha yang dilaksanakan menurut prinsip syariah. Dengan demikian, seluruh perbuatan atau kegiatan usaha apa saja dalam bidang ekonomi yang dilakukan menurut prinsip syariah, maka termasuk dalam jangkauan kewenangan Peradilan Agama. Sedangkan mengenai macam-macam bentuk atau jenis kegiatan yang termasuk dalam bidang ekonomi syariah tidak hanya terbatas pada yang telah disebutkan secara rinci pada penjelasan di atas karena tidak menutup kemungkinan adanya bentuk / jenis kegiatan lain yang tercakup dalam lingkup ekonomi syariah.

Dalam konteks ekonomi syariah, Peradilan Agama memiliki kompetensi absolut dalam memeriksa, memutus dan menyelesaikan perkara diantara para pihak yang terlibat dalam perjanjian (akad) ketika terjadi sengketa diantara mereka. Sengketa ekonomi syariah tersebut dapat terjadi antara lain :

a. Para pihak yang bertransaksi mengenai gugatan wanprestasi, gugatan pembatalan transaksi;

b. Pihak ketiga dan para pihak yang bertransaksi mengenai pembatalan transaksi, pembatalan akta hak tanggungan, perlawanan sita jaminan dan/atau sita eksekusi serta pembatalan lelang. ${ }^{10}$

Secara garis besar sengketa di bidang ekonomi syariah yang menjadi kewenangan Pengadilan Agama dapat diklasifikasikan sebagai berikut ${ }^{11}$ :

1. Sengketa di bidang ekonomi syariah antara lembaga keuangan dan lembaga pembiayaan syariah dengan nasabahnya;

2. Sengketa di bidang ekonomi syariah antara sesama lembaga keuangan dan lembaga pembiayaan syariah;

3. Sengketa di bidang ekonomi syariah antara orang-orang yang beragama Islam, yang mana akad perjanjiannya disebutkan dengan tegas bahwa kegiatan usaha yang dilakukan adalah berdasarkan prinsip-prinsip syariah.

\footnotetext{
${ }^{10}$ H. Hasbi Hasan, Kompetensi Peradilan Agama Dalam Penyelesaian Perkara Ekonomi Syariah, (Jakarta: Gramata Publishing, 2010), hlm. 127.

${ }^{11}$ Abdul Manan, Beberapa Masalah Hukum dalam Praktek Ekonomi Syariah, Makalah Diklat Calon Hakim Angkatan-2 di Banten, 2007, hlm. 8
} 
Kemudian bank syariah merupakan salah satu bidang yang termasuk dalam ruang lingkup ekonomi syariah yang menjadi kewenangan Peradilan Agama. Ketentuan mengenai kompetensi absolut Peradilan Agama dalam perkara ekonomi syariah dituangkan dalam ketentuan UU No.3 Tahun 2006 tentang Perubahan Atas UU No.7 Tahun 1989 tentang Peradilan Agama dan kemudian diperkuat dalam UU No.21 Tahun 2008 tentang Perbankan Syariah. Kedua peraturan tersebut mengatur bagaimana solusi bagi penyelesaian perkara ekonomi syariah.

Kewenangan Peradilan Agama di bidang bank syariah tidak dinyatakan secara spesifik melainkan hanya bersifat global. Dalam penjelasan Pasal 49 huruf i UU No.3 Tahun 2006 menyatakan bahwa "Pengadilan Agama bertugas dan berwenang memeriksa, memutus, dan menyelesaikan perkara di tingkat pertama antara orang-orang yang beragama Islam di bidang...i) ekonomi syariah”. Dan yang dimaksud dengan ekonomi syariah adalah "perbuatan atau kegiatan usaha yang dilaksanakan menurut prinsip syariah, yang antara lain meliputi: a. bank syariah...".

Kalimat "prinsip syariah" sebagaimana disebut dalam Penjelasan Pasal 49 huruf i UU No.3 Tahun 2006 yang juga disebut dalam Pasal 55 ayat (3) UU No.21 Tahun 2008, yang menyatakan bahwa penyelesaian sengketa perbankan syariah baik melalui Pengadilan Agama maupun melalui suatu perjanjian dilakukan melalui prinsip syariah. Pasal 55 ayat (3) UU Perbankan Syariah dimaksud berbunyi, "Penyelesaian sengketa sebagaimana dimaksud pada ayat (2) tidak boleh bertentangan dengan Prinsip Syariah". Dengan demikian dapat disimpulkan bahwa makna ekonomi syariah adalah usaha atau kegiatan usaha yang dilakukan oleh orang seorang, kelompok orang, badan usaha yang berbadan hukum atau yang tidak berbadan hukum dalam rangka memenuhi kebutuhan yang bersifat komersial dan tidak komersial menurut prinsip syariah.

Makna normatif yang ditemukan dalam ketentuan tersebut adalah terdapat tiga unsur pokok persoalan hukum yang harus diperhatikan, yaitu: (a) subjek hukum, (b) kegiatan usaha, dan (c) prinsip syariah. Terkait subjek hukum, dalam ekonomi syariah pada dasarnya tidak memerlukan asas agama Islam, tetapi subjek 
hukum yang dimaksud adalah orang perseorangan, kelompok orang atau persekutuan, badan usaha yang berbadan hukum atau tidak berbadan hukum yang memiliki kecakapan hukum, kemampuan untuk melakukan suatu perbuatan yang dipandang sah secara hukum untuk mendukung hak dan kewajiban. ${ }^{12}$

Adapun ketentuan Pasal 55 UU No.21 Tahun 2008 tentang Perbankan Syariah, yang dinyatakan bahwa:

(1) Penyelesaian sengketa perbankan syariah dilakukan oleh pengadilan dalam lingkungan Peradilan Agama.

(2) Dalam hal para pihak telah memperjanjikan penyelesaian sengketa selain sebagaimana dimaksud pada ayat (1), penyelesaian sengketa dilakukan sesuai dengan isi akad.

(3) Penyelesaian sengketa sebagaimana dimaksud pada ayat (2) tidak boleh bertentangan dengan Prinsip Syariah.

Dan pada penjelasan Pasal 55 ayat (2) khususnya pada huruf d UU No.21 Tahun 2008, yang dimaksud dengan "penyelesaian sengketa dilakukan sesuai dengan isi akad" adalah upaya sebagai berikut:

a) Musyawarah;

b) Mediasi perbankan;

c) Badan Arbitrase Syariah Nasional atau lembaga arbitrase lain; dan/atau

d) Pengadilan dalam lingkungan peradilan umum.

Sebagaimana penjelasan pada Pasal 55 ayat (2) huruf d tersebut, penyelesaian sengketa diselesaikan sesuai akad pada pengadilan dalam lingkungan Peradilan Umum (Pengadilan Negeri). Hal ini terlihat jelas inkonsistensi pada Pasal 55 antara ayat (1) dan (3) dengan ayat (2), terlebih lagi dengan ketentuan Pasal 49 UU No.3 Tahun 2006 tentang Peradilan Agama, yang menimbulkan titik singgung kewenangan antara Peradilan Agama dengan Peradilan Umum. Satu sisi, seluruh sengketa diselesaikan di Pengadilan Agama, tapi di sisi lain membuka kesempatan kepada Pengadilan Negeri, padahal keduanya memiliki kompetensi absolut yang berbeda.

\footnotetext{
${ }^{12}$ H. Hasbi Hasan, Op. Cit., hlm. 130.
} 
Ketentuan Pasal 55 ayat (2) beserta penjelasannya itu menunjukkan bahwa telah terjadi reduksi kompetensi Peradilan Agama dan Peradilan Umum dalam bidang perbankan syariah. Berdasarkan UU No.3 Tahun 2006, Pengadilan Agama memiliki kompetensi dalam menangani perkara ekonomi syariah, yang didalamnya termasuk perkara perbankan syariah. Ternyata ketentuan UU No,3 Tahun 2006 itu dikurangi oleh perangkat hukum lain ketentuan UU No.21 Tahun 2008 yang notabene sebenarnya dimaksudkan untuk memudahkan penanganan perkara ekonomi syariah, khususnya di bidang perbankan syariah.

Dengan demikian, politik hukum pemerintah (legislatif dan eksekutif) terhadap perbankan syariah terkesan masih ambivalen, sebagaimana tercermin dalam Pasal 55 ayat (2) dan penjelasan huruf d yang masih memberi opsi penyelesaian sengketa perbankan syariah melalui pengadilan dalam lingkkungan Peradilan Umum. Adanya opsi kompetensi peradilan dalam lingkungan Peradilan Agama dan Peradilan Umum dalam bidang perbankan syariah ini menunjukkan adanya reduksi dan penyempitan serta mengarah pada dualisme kompetensi mengadili oleh dua lembaga litigasi, sekalipun kompetensi yang diberikan kepada Peradilan Umum adalah terkait dengan akad, khususnya mengenai choice of forum dan choice of jurisdiction.

Adanya choice of forum (choice of litigation) dalam penyelesaian perkara perbankan syariah berdasarkan Pasal 55 ayat (2) UU No. 21 Tahun 2008 tentang Perbankan Syariah menunjukkan inkonsistensi pembentuk undang-undang dalam merumuskan aturan hukum. Pasal 49 UU No.3 Tahun 2006 tentang Peradilan Agama secara jelas memberikan kompetensi kepada Peradilan Agama untuk mengadili perkara ekonomi syariah, termasuk perbankan syariah sebagai suatu kompetensi absolut. Keberadaan choice of litigation akan sangat berpengaruh pada daya kompetensi Peradilan Agama dan tentunya kompetensi Peradilan Agama tidak dapat diperjanjikan.

Pelaksanaan kompetensi dalam perbankan syariah akan sangat bergantung pada isi akad atau kontrak. Jika para pihak mengadakan akad atau kontrak menetapkan penyelesaian perkara pada peradilan di lingkungan Peradilan Umum, maka kompetensi yang dimiliki Peradilan Agama hanya sebatas kompetensi 
secara tekstual sebagaimana diberikan oleh undang - undang, tetapi dalam praktik tidak secara optimal berfungsi karena harus berbagi dengan Pengadilan Negeri, khususnya jika dalam akad telah disebutkan akan diselesaikan di Pengadilan Negeri.

Secara materil substansial Pasal 55 UU No.21 Tahun 2008 tentang Perbankan Syariah telah memunculkan kembali kompetensi absolut Peradilan Umum terhadap sengketa ekonomi syariah yang sebelumnya telah dilimpahkan kepada Peradilan Agama. Penyelesaian sengketa selain melalui Peradilan Agama (mediasi, arbitrase dan peradilan umum) sangat tergantung terhadap kontrak yang dibuat ketika nasabah dan bank melakukan transaksi perbankan. Seperti halnya dalam sengketa perbankan konvensional, penanganannya sangat tergantung kepada kontrak yang dibuat, namun dalam penanganan sengketa perbankan syariah terdapat perbedaan baik secara formil maupun materil.

Perbedaan secara formil, Pengadilan Agama mempunyai kewenangan terhadap penanganan sengketa ekonomi syariah berdasarkan UU No.3 Tahun 2006 jo. UU No.7 Tahun 1989, sedangkan Pengadilan Negeri mempunyai kewenangan menyelesaikan sengketa syariah berdasarkan pada akad yang dibuat saat transaksi perbankan (Pasal 55 ayat (2) UU No.21 Tahun 2008). Adapun kewenangan Pengadilan Negeri dalam menyelesaikan sengketa ekonomi syariah (perdata) pada ketentuan Pasal 50 UU No.8 Tahun 2004 jo. UU No.2 Tahun 1986 tentang Peradilan Umum telah dinasakh (dihapus) oleh UU No.3 Tahun 2006 tentang Peradilan Agama.

Kemudian perbedaan dari sisi materil, kewenangan Pengadilan Agama ditentukan langsung oleh UU No.21 Tahun 2008 tentang Perbankan Syariah, sesuatu yang berbeda yang tidak pernah terjadi pada Pengadilan Negeri, sebab meskipun Pengadilan Negeri berwenang menyelesaikan sengketa perbankan konvensional dan pernah berwenang menyelesaikan sengketa syariah hanya ditetapkan berdasarkan Undang-Undang Peradilan Umum, bukan berdasarkan Undang-Undang Perbankan.

Selain itu, ketentuan Pasal 55 ayat (2) UU No.21 Tahun 2008 jika dipahami berdasarkan teori hukum perjanjian, maka ketentuan tersebut adalah terkait 
adanya asas kebebasan berkontrak. Islam memberikan kebebasan kepada para pihak untuk melakukan suatu perikatan, dan bentuk isi perikatan tersebut ditentukan oleh para pihak. Apabila telah disepakati bentuk dan isinya, maka perikatan para pihak yang menyepakatinya dan harus dilaksanakan segala hak dan kewajibannya. Namun kebebasan ini tidak bersifat absolut, sepanjang tidak bertentangan dengan syariah Islam, maka perikatan tersebut boleh dilaksanakan. ${ }^{13}$ Menurut Prof. Faturrahman Djamil, bahwa syariah Islam memberikan kebebasan kepada setiap orang yang melakukan akad sesuai dengan yang diinginkan, tetapi yang menentukan akibat hukumnya adalah ajaran agama. ${ }^{14}$

Pasal 1338 KUHPerdata ayat (1) menyebutkan, "semua perjanjian yang dibuat secara sah berlaku sebagai undang - undang bagi mereka yang membuatnya". Kata "semua" dipahami mengandung asas kebebasan berkontrak, yaitu suatu asas yang memberikan kebebasan pada para pihak untuk; (a) membuat atau tidak membuat perjanjian; (b) mengadakan perjanjian dengan siapa pun; (c) menentukan isi perjanjian, pelaksanaan, dan persyaratannya; dan (d) menentukan bentuk perjanjian baik secara tertulis maupun lisan.

Munculnya isi perjanjian dimana para pihak menyepakati jika terjadi suatu sengketa akan diselesaikan melalui jalur litigasi atau non litigasi merupakan kebebasan para pihak dalam menentukan isi suatu perjanjian. Terdapat dua cara dalam menentukan pilihan dimana sengketa akan diselesaikan berdasarkan belum atau sudah terjadinya sengketa, yaitu melalui factum de compromittendo dan acta compromis. factum de compromittendo merupakan kesepakatan para pihak yang mengadakan perjanjian berdasarkan domisili hukum yang akan dipilih tatkala terjadi sengketa. Ketentuan ini biasa dicantumkan dalam kontrak atau akad yang merupakan klasula antisipatif. Sedangkan acta compromis adalah suatu perjanjian tersendiri yang dibuat setelah terjadinya sengketa. Ketentuan ini merupakan pilihan tempat penyelesaian sengketa yang lebih mengarah pada wilayah yurisdiksi pengadilan dalam satu lingkungan peradilan, bukan pilihan terhadap peradilan di lingkungan yang berbeda.

\footnotetext{
${ }^{13}$ Gemala Dewi, dkk., Hukum Perikatan Islam di Indonesia, (Jakarta: Kencana, 2005), hlm. 31.

${ }^{14}$ Faturrahman Djamil, Hukum Perjanjian Syariah, dalam Kompilasi Hukum Perikatan oleh Mariam Darus Badrulzaman, (Bandung: Citra Aditya Bakti, 2001), hlm. 249.
} 
Sehubungan dengan ketentuan Pasal 55 UU No.21 Tahun 2008 beserta penjelasannya, Harry Azhar mantan Anggota Panitia Khusus (Pansus) RUU Perbankan Syariah menyatakan bahwa "yang mempunyai kekuatan hukum adalah terletak pada isi pasal, bukan pada penjelasannya". ${ }^{15}$ Satu sisi pernyataan tersebut dapat dibenarkan bahwa ketentuan yang mengikat dalam peraturan perundangundangan khususnya UU No.21 Tahun 2008 tentang Perbankan Syariah adalah pada isi pasal-pasalnya, namun bukan berarti menafikan ketentuan yang ada pada penjelasannya.

Dengan demikian, antara isi pasal dan penjelasannya merupakan satu kesatuan yang mengikat dan tidak dapat terpisahkan dari isi pasal untuk membentuk sebuah aturan dan memberikan penjelasan kepada masyarakat sebagai hukum yang dapat dijadikan landasan bagi seluruh kegiatan usaha khususnya bank syariah. Sehingga tujuan dari hukum dapat terwujud dengan baik. Oleh karena itulah setiap peraturan perundang-undangan selalu diikuti dengan penjelasannya dan peraturan pelaksananya.

Kemudian, masih dalam kontek ketentuan Pasal 55 UU No.21 Tahun 2008, Abdul Gani Abdullah ${ }^{16}$ (Hakim Agung) telah mengemukakan analisis normatifyuridis atas ketentuan tersebut. Mengenai ayat (1), telah menjadi prinsip hukum bahwa penyelesaian perkara perbankan syariah melalui proses litigasi menjadi kompetensi absolut pengadilan dalam lingkungan Peradilan Agama. Terkait dengan penafsiran ayat (2) dapat dijelaskan bahwa ayat (1), yakni litigasi, harus berhadapan dengan ayat (2), yakni non litigasi, musyawarah, mediasi perbankan, Basyarnas atau lembaga arbitrase lain, dan / atau pengadilan dalam lingkungan Peradilan Umum. Dalam struktur undang-undang ini, pengadilan dalam lingkungan Peradilan Umum diposisikan sebagai non litigasi, karena Peraadilan Umum merupakan lembaga litigasi, maka dalam undang-undang ini terdapat penempatan norma yang keliru.

\footnotetext{
${ }^{15}$ www.hukumonline.com

${ }^{16}$ Abdul Gani Abdullah, "Solusi Penyelesaian Sengketa Perbankan Syariah Menurut Pasal 49 UU No.3 Tahun 2006 tentang Perubahan Atas UU No.7 Tahun 1989 tentang Peradilan Agama dan Pasal 55 UU No.21 Tahun 2008 tentang Perbankan Syariah". Makalah disampaikan pada tanggal 7 Februari 2009 di Yogyakarta.
} 
Dengan demikian, dalam penjelasan Pasal 55 ayat (1) dan ayat (2) telah terjadi contradictio in terminis. Maka berdasarkan analisis atas kaidah tersebut, frasa "Pengadilan dalam lingkungan Peradilan Umum" yang telah memposisikan Peradilan Umum pada posisi non litigasi dapat dikesampingkan oleh hakim karena cara penyelesaian melalui Peradilan Umum adalah merupakan cara penyelesaian di luar litigasi. Penafsiran yuridis inilah yang kemudian mendorong Mahkamah Agung untuk melakukan langkah dengan mengambil jalan yuridis untuk memperlancar penyelenggaraan peradilan dengan menyerahkan perkara perbankan syariah pada kompetensi pengadilan dalam lingkungan Peradilan Agama.

Selain analisa yang telah disebutkan di atas, untuk mengetahui jangkauan kewenangan peradilan agama dalam memeriksa, mengadili, memutus dan menyelesaikan sengketa di bidang perdata sebagaimana telah disebutkan dalam Penjelasan angka 37 Pasal 49 UU No. 3 Tahun 2006, dapat dilakukan analisis dengan beberapa pendekatan seperti asas personalitas keislaman, asas penundukan diri dan asas lex specialis derogate legi generalis. Pendekatan analisis berdasarkan ketiga asas tersebut dapat dijabarkan sebagai berikut :

\section{Asas Personalitas Keislaman.}

Asas personalitas keislaman adalah merupakan salah satu asas yang berlaku dan ditetapkan berdasarkan UU No.3 Tahun 2006 yang menjadi sebagai pedoman umum dalam menentukan kewenangan Peradilan Agama. Asas personalitas keislaman adalah asas pemberlakukan hukum Islam terhadap orang yang beragama Islam baik secara subyektif maupun obyektif.

Pemberlakuan hukum Islam secara subyektif adalah setiap orang Islam sebagai subyek hukum harus tunduk kepada hukum Islam, sehingga segala tindakannya harus dianggap dilakukan menurut hukum Islam, dan jika tidak dilakukan berdasarkan hukum Islam maka dianggap melakukan suatu pelanggaran. Sedangkan pemberlakuan hukum Islam secara obyektif adalah segala sesuatu yang menyangkut aspek hukum orang Islam sebagai obyek hukum harus diukur dan dinilai berdasarkan hukum Islam. 
Pemberlakuan asas personalitas keislaman termasuk semua badan hukum Islam yang ada dalam sistem hukum di Indonesia khususnya bank syariah mengenai status hukum maupun perbuatan dan peristiwa hukum yang terjadi, termasuk hubungannya dengan orang perseorang atau badan hukum lain serta termasuk mengenai hak milik badan hukum tersebut.

Dengan demikian, dapat disimpulkan bahwa apabila terjadi sengketa perbankan syariah khususnya pembiayaan syariah yang jelas dan nyata dalam perjanjian yang dibuat dan telah disepakati berdasarkan prinsip-prinsip syariah, atau dengan kata lain sepanjang berkaitan dengan prinsip-prinsip syariah, maka secara otomatis sengketa tersebut diselesaikan berdasarkan hukum Islam.

2. Asas Penundukan diri.

Berdasarkan asas penundukan diri secara sukarela sebagaimana disebutkan dalam penjelasan Pasal 49 UU No. 3 Tahun 2006 dinyatakan bahwa "Pengadilan agama bertugas dan berwenang memeriksa, memutus dan menyelesaikan perkara di tingkat pertama antara orang-orang yang beragama Islam di bidang...". Kalimat "antara orang yang beragama Islam" secara tekstual dapat dipahami bahwa jangkauan kewenangan peradilan agama hanya terbatas pada bidangbidang yang telah ditentukan oleh Pasal 49 tersebut, khususnya di bidang bank syariah, dan hanya sebatas sengketa yang terjadi antara orang-orang yang beragama Islam saja.

Sedangkan tinjauan kontekstual dari ketentuan tersebut adalah setiap person dan badan hukum yang mengikat diri dalam kontrak berdasarkan prinsip syariah, secara tidak langgsung telah mengikatkan diri (pacta sunt servanda) untuk menyelesaikan perkara berdasarkan hukum Islam. Asas pacta sunt servanda yang disebut juga dengan asas kepastian hukum merupakan asas yang berhubungan dengan akibat perjanjian. Asas tersebut harus ditaati sebagai subtansi kontrak yang dibuat oleh para pihak berdasarkan hukum Islam dan berlaku sebagai undang-undang bagi mereka yang membuatnya (Pasal 1338 KUHPerdata).

Para pihak dalam membuat perjanjian berdasarkan prinsip syariah tidak dapat melakukan pilihan hukum untuk diadili di pengadilan selain di lingkungan Peradilan Agama, sebagaimana tercantum dalam penjelasan umum UU No. 3 
Tahun 2006 alenia ke-2, bahwa pilihan hukum telah dinyatakan dihapus. Oleh karena itu dalam draft-draft perjanjian yang dibuat oleh beberapa perbankan syariah berkaitan dengan perjanjian atau akad yang lain yang masih mencantumkan klausul penyelesaian sengketa di Pengadilan Negeri, maka klausul tersebut harus dirubah menjadi kewenangan Pengadilan Agama dalam menyelesaikan sengketa tersebut.

Disamping itu, dalam pendirian bank syariah, tidak ditemukan ketentuan yang mengkhususkan bahwa bank syariah hanya diperuntukan bagi orang-orang yang beragama Islam saja, atau sebaliknya melarang orang-orang yang selain beragama Islam untuk bertransaksi atau menjadi mitra dan nasabah di bank syariah. Hal itu berarti, seluruh kegiatan yang terkait dengan bank syariah baik dalam bertransaksi maupun untuk menjadi mitra dan nasabah di bank syariah berlaku secara umum tidak terbatas pada golongan atau agama tertentu saja.

Oleh karena itu, berdasarkan ketentuan Pasal 49 dan penjelasannya tersebut dapat dipahami bahwa yang tunduk dan dapat ditundukkan ke dalam kewenangan lingkungan Peradilan Agama tidak lagi hanya terbatas pada mereka yang beragama Islam, tetapi termasuk mereka yang beragama selain Islam (non-Islam). Asas penundukan diri tersebut, dalam hal ini seseorang atau suatu badan hukum dianggap menundukkan diri terhadap hukum Islam apabila ia melakukan suatu kegiatan usaha di bidang ekonomi khususnya bank syariah yang didasarkan pada prinsip syariah.

Hal ini berarti ruang lingkup kewenangan Peradilan Agama tidak hanya terbatas pada sengketa yang terjadi antara sesama Islam saja, melainkan meliputi sengketa yang terjadi antara orang Islam dengan non Islam, bahkan termasuk sengketa yang terjadi antar sesama orang non Islam sekalipun, sepanjang sengketa tersebut termasuk dalam ruang lingkup bidang-bidang yang menjadi kewenangan lingkungan Peradilan Agama.

3. Asas Lex specialis Derogate Legi Generalis. 
Selain kedua asas tersebut, terdapat asas lex specialis derogate legi generalis, ${ }^{17}$ yaitu aturan khusus mengenyampingkan aturan yang umum. Dalam hal sengketa syariah ketentuan UU No.3 Tahun 2006 tentang Peradilan Agama adalah sebagai aturan khusus yang mengenyampingkan ketentuan Pasal 55 ayat (2) dan penjelasannya pada huruf d UU No.21 Tahun 2008 tentang Perbankan syariah yang merupakan aturan umum. Terlebih lagi, frasa "Pengadilan dalam lingkungan Peradilan Umum" posisinya terletak pada posisi non litigasi yang dapat dikesampingkan oleh hakim karena cara penyelesaian melalui Peradilan Umum (Pengadilan Negeri) adalah merupakan cara penyelesaian di luar litigasi. Padahal semestinya penyelesaian melalui Peradilan Umum adalah merupakan cara penyelesaian litigasi.

Berdasarkan asas hukum tersebut maka Pengadilan Negeri sudah tidak berwenang lagi menyelesaikan sengketa ekonomi syariah, kecuali dalam hal sengketa yang berkaitan dengan hak milik atau sengketa keperdataan lain antara orang - orang yang beragama Islam dengan orang-orang non Islam mengenai sengketa sebagaimana dimaksud dalam Pasal 49 UU No.3 Tahun 2006 tentang Peradilan Agama. Bahkan dalam hal penyelesaian sengketa perbankan syariah diajukan ke Pengadilan Negeri dapat diajukan eksepsi kompetensi absolut berdasarkan analisa sebagaimana telah dijelaskan di atas dan kajian pendekatan berdasarkan asas personalitas keislaman, asas penundukan diri dan asas lex specialis derogate legi generalis.

Dengan demikian, terhadap orang Islam berlaku hukum Islam dan jika terjadi sengketa ekonomi syariah khususnya bank syariah diselesaikan menurut hukum Islam oleh pengadilan agama, karena terikat dalam 3 (tiga) asas hukum, yaitu asas personalitas dan asas penundukan diri dengan sukarela kepada hukum Islam yang terdapat pada UU No.3 Tahun 2006 tentang Peradilan Agama. Analoginya, seperti halnya kaum Thionghoa dahulu yang harus tunduk pada BW,

\footnotetext{
${ }^{17}$ Asas ini menerangkan bahwa peraturan yang lebih umum akan dikesampingkan dengan peraturan yang lebih khusus, seperti Pasal 50 UU No.8 Tahun 2004 jo. UU No.2 Tahun 1986 mengenai pemberian kewenangan kepada Pengadilan Negeri untuk menyelesaikan sengketa perdata termasuk perbankan syariah dikesampingkan oleh Pasal 49 UU No.3 Tahun 2006 jo. UU No.7 Tahun 1989. Begitu juga ketentuan Pasal 50 ayat (2) dan pada penjelasannya khususnya ayat (2) huruf d UU No.21 Tahun 2008 tentang Perbankan Syariah dikesampingkan oleh Pasal 49 UU No.3 Tahun 2006 tentang Peradilan Agama.
} 
meskipun sebenarnya tidak termasuk pribumi. Dan terakhir berdasarkan asas lex specialis derogate legi generalis sebagaimana asas yang berlaku dalam peraturan dan perundang - undangan di Indonesia.

\section{Penerapan Sanksi Denda dan Uang Paksa (dwangsom) Dalam Penyelesaian Sengketa Syariah}

Sistem hukum Indonesia mengikuti tradisi civil law yang ciri utamanya adalah peraturan perundang-undangan yang terkodifikasi. Menurut Bagir Manan sistem hukum Indonesia adalah sistem hukum kontinental (continental legal system) yang merupakan bagian dari warisan hukum kolonial Belanda yang berasal dari daratan Eropa, atau sistem hukum sivil (the civil legal system) yang berkaitan dengan hukum perdata atau sistem hukum kodifikasi (codified legal system). Serta codified legal system menunjukkan bahwa hukum dalam tatanan Indonesia identik dengan undang-undang. ${ }^{18}$

Sementara itu hukum Islam walaupun mempunyai sumber-sumber tertulis dalam Al - Qur'an, dan As - Sunnah serta pendapat para fuqaha (doktrin fiqih) pada umumnya tidak terkodifikasi dalam bentuk perundang-undangan yang mudah dirujuk. Oleh karena itu, hukum Islam di Indonesia seperti halnya juga hukum adat, sering dipandang sebagai hukum tidak tertulis dalam bentuk perundang-undangan. ${ }^{19}$ Dan mustahil kalau seluruh hukum tidak tertulis (tersirat) dapat diakomodir atau diwujudkan dalam bentuk perundang-undangan (hukum positif), terlebih lagi hukum Islam yang universal. Oleh karena itu, yang terpenting adalah bagaimana hukum tidak tertulis (tersirat) dikaji dan digali secara komprehensif dan secara subtansi diakomodir dalam peraturan perundangundangan (hukum positif) dalam menyelesaikan sengketa pembiayaan perbankan syariah untuk menegakkan hukum serta memenuhi rasa keadilan di tengah masyarakat dan tidak bertentangan dengan ketentuan syariah.

\footnotetext{
${ }^{18}$ Bagir Manan, Dissenting Opinion Dalam Sistem Peradilan Indonesia, Varia Peradilan No. 253, 2006, hlm. 6 .

${ }^{19}$ Rifyal Ka'bah, Kodifikasi Hukum Islam Melalui Perundang-Undangan Negara di Indonesia, Majalah Hukum Suara Uldilag Vol.II No.5, Jakarta, September 2004, hlm. 50.
} 
Prinsip utama yang harus benar-benar dipahami dan diperhatikan dalam menangani perkara di bidang ekonomi syariah adalah proses penyelesaiannya tidak boleh bertentangan dengan prinsip-prinsip syariah (Pasal 1 ayat (7) jo. Pasal 2 UU No.21 Tahun 2008 tentang Perbankan Syariah), terlebih harus mengkaji secara mendalam nilai-nilai syariah yang terkandung dalam suatu perkara tersebut karena terkait hukum acara dan sebagian hukum materil yang berlaku di Peradilan Agama sebenarnya bukan ditujukan untuk menegakkan dan melaksanakan hukum syariah., sehingga diharapkan nilai-nilai syariah yang tersirat dapat mewujudkan suatu keadilan dan sesuai dengan ketentuan syariah.

Terlepas dari itu, fakta menunjukkan bahwa peraturan perundang-undangan tersebut telah menjadi ketentuan formil dan materiil yang berlaku dalam menyelesaikan sengketa syariah, dan ketentuan itu secara umum tidak banyak bertentangan dengan hukum syariah, namun bukan berarti semua ketentuan tersebut telah sesuai dengan hukum syariah dalam menyelesaikan sengketa khususnya perbankan syariah. Oleh karena itu, tidak menutup kemungkinan terdapat ketentuan-ketentuan tertentu yang apabila diterapkan mengikuti standarisasi seperti yang diterapkan di Peradilan Umum tanpa pemahaman yang komprehensif terhadap nilai - nilai yang terkandung dalam syariah, justru akan bertentangan dengan prinsip syariah dan bahkan akan menimbulkan permasalahan lain.

Oleh karena itu, untuk menjaga proses peradilan dalam menyelesaikan sengketa syariah tetap sesuai dengan koridor ketentuan syariah, maka para hakim Peradilan Agama khususnya harus mengkaji dan menemukan hukum (rechtvinding) yang tersirat berdasarkan sumber utama hukum Islam yaitu Al Quran dan As - Sunnah, serta sumber pendukung lainnya seperti ijtihad, ijma', qiyas, istihsan, maslahah mursalah, urf, istishab. Ijtihad merupakan sarana untuk menggali hukum Islam dengan metode ijma', qiyas. Kemudian dalam pembahasan teori hukum Islam, pembentukan hukum lebih mengedepankan metode untuk memperoleh hukum yang kemudian menjadi landasan hukum bagi perilaku seorang mukallaf (dewasa). Oleh karena pembahasannya diawali dari adanya kesepakatan mengenai sumber hukum Islam (Al - Quran dan As - Sunnah), maka 
selanjutnya sejauh mana dapat memperoleh hukum yang dianggap benar atau senada dengan kehendak Al - Quran dan As - Sunnah, meskipun tidak ada dalil dari keduanya.

Apabila teori hukum Islam dikaitkan dengan perjanjian dalam transaksi perbankan syariah khususnya menyangkut klausul penyelesaian sengketa, tampaknya teori hukum Islam tidak membahas hukum perjanjian ini secara tersendiri seperti halnya dalam hukum perdata. Sehingga pemberlakuan perjanjian sebagai sumber hukum bagi yang membuatnya (mukallaf) akan dinilai sejauh mana materi perjanjian tersebut sesuai dengan hukum. Dengan metode ijtihad istihsan memungkinkan untuk menjadikan perjanjian sebagai salah satu sumber hukum Islam. Istihsan mempunyai relevansi untuk melakukan pembaharuan hukum Islam demi memelihara kemasalahatan manusia. ${ }^{20}$ Dan merupakan sebagai pilihan hukum kepada putusan yang lebih mencerminkan rasa keadilan dan kemaslahatan masyarakat. $^{21}$

Beberapa ayat Al - Quran dan hadits telah memerintahkan untuk melaksanakan perjanjian yang harus dipatuhi. Dalam konteks perbankan syariah telah diatur dalam peraturan dan perundang - undangan serta peraturan terapan pendukung lainnya seperti Peraturan Bank Indonesia (PBI), Surat Edaran Bank Indonesia (SEBI), serta fatwa yang dikeluarkan oleh Dewan Syariah Nasional Majelis Ulama Indonesia (DSN-MUI). Penyelesaian sengketa syariah harus cermat dan teliti dalam memberikan pertimbangkan hukum sehingga putusan yang diambil dapat memberikan rasa keadilan dan sesuai dengan ketentuan syariah, dan tentunya juga sesuai dengan ketentuan dan prinsip syariah dalam konteks kegiatan perbankan syariah.

Adapun ketentuan-ketentuan yang terdapat dalam hukum formil dan materiil seperti HIR, R.Bg, Rv, dan BW (KUHPerdata) yang juga berlaku dan digunakan untuk menyelesaikan sengketa dilingkungan Peradilan Umum. Apabila ketentuan tersebut diterapkan oleh Peradilan Agama dalam memutus sengketa khususnya perbankan syariah tanpa mempertimbangkan aspek syariah secara komprehensif,

\footnotetext{
200.

${ }^{20}$ Iskandar Usman, Istihsan dan Pembaharuan Hukum Islam, (Jakarta: Raja Grafindo Persada, 1994), hlm.

${ }^{21}$ Jaih Mubarok, Metodologi Ijtihad Hukum Islam, (Yogyakarta: UII Press, 2002), hlm. 124
} 
maka justru penerapan ketentuan tersebut akan bertentangan dengan prinsip syariah yang melekat pada kegiatan bank syariah, seperti dalam hal penerapan denda terhadap setiap keterlambatan pembayaran oleh nasabah (tergugat). Dan penerapan dwangsom (uang paksa) terhadap perbuatan wanprestasi (ingkar janji) dari perjanjian yang telah dibuat dan disepakati bersama oleh para pihak.

Penerapan denda dipandang oleh sebagian ulama mengandung unsur ribawi yang jelas tidak diperbolehkan dalam syariah dan itu merupakan prinsip dasar yang membedakan bank syariah dengan bank konvensional. Dan sebagian ulama lagi mendukung pemberian sanksi denda tersebut karena berpandangan bahwa pemberian sanksi denda tersebut untuk menegakkan maqasid asy-syariah (tujuan syariah) demi kemaslahatan. Oleh karena itu, dalam hal ini pendapat ulama yang mendukung pemberian sanksi denda lebih relevan pada saat ini, namun dalam penerapan denda tetap harus memperhatikan hal-hal tertentu yang menjadi dasar diperbolehkannya penerapan sanksi denda tersebut.

Penetapan denda dalam putusan Pengadilan Agama, yang dalam amar putusannya mengabulkan permintaan denda terhadap setiap keterlambatan pembayaran sejumlah uang oleh pihak nasabah (tergugat), harus memperhatikan firman Allah SWT dalam (QS. Al - Baqarah: 280). Pada ayat tersebut memerintahkan agar memberikan kemudahan kepada orang (nasabah penerima fasilitas pembiayaan) yang tidak dapat membayar utang karena dalam kondisi kesukaran dan kesempitan, bahkan menyedekahkan sebagian atau seluruh dari utang tersebut akan lebih baik. Penjelasan dalil Al - Quran tersebut, juga didukung oleh sebuah hadis yang diriwayatkan oleh Bukhari dan Muslim yang menjelaskan bahwa penundaan pembayaran utang oleh orang kaya adalah perbuatan dzalim. Dan fatwa Dewan Syariah Nasional Majelis Ulama Indonesia (DSN-MUI) No.17/DSN-MUI/IX/2000 tentang Sanksi Atas Nasabah Mampu yang Menunda-nunda Pembayaran.

Dengan demikian, berdasarkan dalil Al - Quran dan Al - Hadis serta fatwa DSN-MUI tersebut di atas, bahwa bank syariah sudah sepatutnya dan diperbolehkan untuk meminta atau menerapkan denda sebagai sanksi yang dijatuhkan kepada nasabah penerima fasilitas pembiayaan (Tergugat). Sanksi atau 
hukuman denda tersebut boleh dijatuhkan terhadap nasabah penerima fasilitas pembiayaan (Tergugat) yang dalam keadaan mampu terbukti sengaja lalai dan menunda-nunda untuk melaksanakan kewajibannya melakukan pembayaran utang. Asumsinya nasabah yang sedang dalam kondisi kesulitan tidak mungkin lalai terhadap kewajibannya melainkan keterlambatan pembayaran utang disebabkan oleh kondisi yang sulit tersebut.

Dalam penerapan sanksi denda dan besaran jumlahnya harus disepakati dalam akad yang telah ditandatangani bersama oleh para pihak. Pemberian sanksi tersebut berdasarkan prinsip ta'zir, yaitu bertujuan untuk menjaga dan menegakkan maqasyd asy syariah agar nasabah lebih disiplin dalam melaksanakan kewajibannya. Tujuan syariah (maqasyd asy syariah) dapat diklasifikasikan menjadi 5 hal pokok, yaitu: (1) menjaga agama (hifzh ad-din), (2) menjaga jiwa (hifzh an-nafs); (3) menjaga akal (hifzh al-aql); (4) menjaga keturunan (hifzh an-nasl); (5) menjaga harta (hifzh al-mal) (Asy-Syatibi, AlMuwâfaqât, II/4-5; Az - Zuhayli, Ushûl al-Fiqh al-Islâmî, II / 1046-1051).

Kemudian, begitu juga dalam hal Pengadilan Agama mengabulkan dalam amar putusannya yang menetapkan uang paksa (dwangsom) sebagai sanksi yang diberikan kepada orang (nasabah penerima fasilitas pembiayaan) yang tidak melakukan suatu perbuatan sebagaimana mestinya (wanprestasi) dalam waktu yang telah ditentukan oleh bank syariah berdasarkan perjanjian yang telah disepakati, yang seharusnya mendapat keuntungan dari pemberian pembiayaan tersebut. Dalam hal ini untuk kepentingan pemenuhan perbuatan (prestasi) tersebut dinilai dalam jumlah uang (ganti rugi) sebagai sanksi yang diberikan berupa dwangsom (uang paksa).

Mengenai dwangsom diatur dalam Pasal 606 huruf a dan b B.Rv, Pasal 225 HIR, 259 R.Bg, yaitu gugatan untuk melakukan suatu persetujuan / perjanjian berdasarkan Pasal 1267 KUHPerdata. Menurut Yahya M. Harahap, dalam bukunya berpendapat bahwa dwangsom tersebut tidak berlaku terhadap tindakan untuk membayar sejumlah uang, melainkan hanya merupakan hukuman pengganti atas keingkaran mengosongkan atau menyerahkan sesuatu barang obyek sengketa. Penerapan $d$ wangsom (uang paksa) diperlukan pengkajian dan pemahaman yang 
komprehensif terhadap nilai-nilai syariah agar tidak bertentangan dengan prinsip syariah (Pasal 1 ayat (7) jo. Pasal 2) UU No.21 Tahun 2008 tentang Perbankan Syariah. Oleh karena itu, dalam hal penerapan dwangsom (uang paksa) harus mengacu kepada dalil Al - Quran dan Al - Hadits, serta fatwa DSN No.17/DSNMUI/IX/2000 seperti halnya pada penerapan denda tersebut diatas.

Dwangsom dilihat sebagai sanksi yang dapat disamakan dengan denda yang dapat dijatuhkan kepada nasabah yang melakukan perbuatan wanprestasi (ingkar janji) atau tidak melakukan sesuatu dalam waktu yang telah ditentukan terhadap perjanjian yang telah dibuat dan disepakati. Perbuatan wanprestasi itu mengakibatkan timbulnya kerugian oleh pihak bank syariah, oleh sebab itu, perlu dijatuhkan sanksi kepada nasabah berupa uang pengganti (ganti rugi) terhadap nilai kerugian yang disebabkan oleh perbuatan wanprestasi tersebut.

Perbuatan wanprestasi tersebut perlu dikaji penyebabnya secara komprehensif apakah disebabkan oleh sesuatu hal diluar kemampuan nasabah atau justru ada unsur kesengajaan dan kelalaian yang berakibat fatal, sehingga terjadinya perbuatan wanprestasi tersebut. Jika perbuatan wanprestasi itu disebabkan adanya unsur kesengajaan dan kelalaian dengan maksud tertentu, maka sanksi berupa dwangsom (uang paksa) boleh dijatuhkan terhadap nasabah yang melakukan perbuatan wanprestasi sebagai uang ganti rugi atas hilangnya keuntungan yang semestinya diperoleh oleh bank syariah yang disebabkan oleh perbuatan wanprestasi tersebut.

Dan apabila penerapan uang paksa (dwangsom) tanpa mendasarkan pada dalil sebagaimana telah dibahas di atas, atau dengan kata lain apabila keputusan penerapan dwangsom (uang paksa) dijatuhkan kepada nasabah yang sedang mengalami kesulitan dan kesukaran sehingga menyebabkan ia tidak mampu untuk melakukan pembayaran tepat waktu, tentu hal ini bertentangan dengan prinsip syariah, terlebih lagi dalam akad perjanjian tidak mencantumkan klausul sanksi dwangsom (uang paksa).

Dengan demikian, berasarkan dalil Al - Quran dan Al - Hadits serta fatwa DSN-MUI tersebut dapat dijadikan landasan sebagai dasar hukum diperbolehkannya penerapan sanksi denda dan dwangsom. Baik penerapan sanksi 
denda terhadap setiap keterlambatan pembayaran utang oleh nasabah mampu yang sengaja melalaikan dan menunda-nunda kewajibannya untuk melaksanakan pembayaran, maupun sanksi dwangsom (uang paksa) terhadap perbuatan wanprestasi yang dilakukan dengan unsur kesengajaan dan kelalaian, maka sanksi tersebut dapat dijatuhkan sepanjang telah disepakati dalam akad bertujuan untuk menjaga dan menegakkan maqasyd syariah agar nasabah lebih disiplin dalam melaksanakan kewajibannya.

\section{PENUTUP}

\section{Kesimpulan}

Berdasarkan uraian-uraian yang telah di jelaskan pada bab - bab sebelumnya, maka penulis akan merumuskan suatu kesimpulan, yaitu :

1. Penyelesaian sengketa ekonomi syariah merupakan kewenangan Peradilan Agama berdasarkan ketentuan Pasal 49 UU No.3 Tahun 2006 tentang Peradilan Agama, yang diperkuat dengan ketentuan Pasal 55 UU No.21 Tahun 2008. Ketetuan Pasal 55 ayat (1) dan ayat (2) telah terjadi contradictio in terminis. Posisi Peradilan Umum pada penjelasan ayat (2) huruf d merupakan penempatan norma yang keliru sebagai lembaga non litigasi. Selain itu, berlaku juga asas personalitas keislaman, asas penundukan diri secara sukarela kepada hukum Islam dan asas lex specialis derogate legi generalis, yaitu aturan khusus (UU No.3 Tahun 2006) mengenyampingkan aturan yang umum (UU No.21 Tahun 2008). Asas kebebasan berkontrak (Pasal 1338 KUHPerdata) tidaklah bersifat absolut sepanjang bertentangan dengan syariah.

2. Pemberian sanksi denda dan dwangsom (uang paksa) tersebut diperbolehkan oleh syariah dan tidak bertentangan dengan dalil-dalil Al - Quran (QS. Al Baqarah: 280) dan Al - Hadits serta fatwa DSN No.17/DSN-MUI/IX/2000 sebagai sanksi atas kesengajaan menunda-nunda pembayaran utang dan perbuatan wanprestasi, demi menegakkan maqasid asy syariah. 


\section{Saran}

Berdasarkan kesimpulan di atas, maka saran-saran yang dapat diberikan Penulis, di antaranya :

1. Bahwa petunjuk Mahkamah Agung sangat diperlukan terhadap penyelesaian sengketa ekonomi syariah terkait ketentuan yurisdiksi antara Peradilan Agama dengan Peradilan Umum yang terjadi titik singgung kewenangan mengadili (contradictio in terminis).

2. Demi kepastian hukum, perlu dilakukan amandemen atau permohonan judicial review terhadap ketentuan Pasal 55 ayat (2) dan penjelasannya pada huruf c dan d UU No. 21 Tahun 2008 tentang Perbankan Syariah.

\section{DAFTAR PUSTAKA}

Abdullah, Abdul Ghani,"Solusi Penyelesaian Sengketa Perbankan Syariah Menurut Pasal 49 UU No.3 Tahun 2006 tentang Perubahan Atas UU No.7 Tahun 1989 tentang Peradilan Agama dan Pasal 55 UU No.21 Tahun 2008 tentang Perbankan Syariah”. Makalah disampaikan pada tanggal 7 Februari 2009 di Yogyakarta.

Dewi, Gemala, dkk., 2005, Hukum Perikatan Islam di Indonesia, Jakarta: Kencana.

Djamil, Fathurrahman, 2001, Hukum Perjanjian Syariah, dalam Kompilasi Hukum Perikatan, Bandung: Citra Aditya Bakti.

Harahap, M. Yahya, 2005, Hukum Acara Perdata, Jakarta: Sinar Grafika.

Hasan, Hasbi, 2010, Kompetensi Peradilan Agama Dalam Penyelesaian Perkara Ekonomi Syariah, Jakarta: Gramata Publishing.

Hermansyah, 2005, Hukum Perbankan Nasional Indonesia, Jakarta: Kencana Media Group.

Ka'bah, Rifyal, 2004, Kodifikasi Hukum Islam Melalui Perundang-Undangan Negara di Indonesia, Majalah Hukum Suara Uldilag Vol.II No.5, Jakarta.

Manan, Bagir, 2006, Dissenting Opinion Dalam Sistem Peradilan Indonesia, Varia Peradilan No. 253. 
Manan, Abdul, 2007, Beberapa Masalah Hukum dalam Praktek Ekonomi Syariah, Makalah Diklat Calon Hakim Angkatan-2 di Banten.

Mubarok, Jaih, 2002, Metodologi Ijtihad Hukum Islam, Yogyakarta: UII Press.

Sutiyoso, Bambang, 2006, Penyelesaian Sengketa Bisnis, Yogyakarta: Citra Media.

Usman, Iskandar, 1994, Istihsan dan Pembaharuan Hukum Islam, Jakarta: Raja Grafindo Persada.

Fatwa DSN No.17/DSN-MUI/IV/2005 tentang Sanksi Atas Nasabah Mampu yang Menunda-nunda Pembayaran.

http://omperi.wikidot.com/Sejarah Perkembangan Hukum Perbankan Syariah Di Indonesia.

$\underline{\text { www.hukumonline.com }}$ 